Siv S. Limstrand

Gateprest i Kirkens Bymisjon i Trondheim

Foto Mari Vold

\title{
Død, sorg, folkehelse og forskjeller
}

\author{
Er det noe arbeidet mitt har lært \\ meg, så er det at det er ikke stor \\ forskjell på oss.
}

Jeg satt i bilen, hadde fire timers kjøring foran meg. Var på hjemvei etter å ha forretta en begravelse. Hodet var fullt av tanker etter to intense dager. Sorgsamtalene med pårørende, som i dette tilfellet var min ganske nære familie.

Forberedelsesarbeidet satte mange følelser i sving i meg, som i de andre. Kjente på privilegiet det er å tilhøre en familie. Hvor godt det er å kunne bidra med noe man kan. Men også ydmykheta over tilliten jeg var gitt. Det er mye som står på spill, det skal bli riktig. Det skal bli riktig både som uttrykk for det levde livet og for sorgen. Og for så mange. Både forberedelser og begravelse skal være stabbesteiner i sorgprosessen. Noe skal åpnes. Noe skal lukkes. Bidra inn mot de tunge dagene som kommer. Den nye tidsregninga. Livet uten ei mor. Det er nå det begynner.

Alt dette satt i kroppen på meg. Bildet av varme klemmer i minnesamværet, gråt og latter om hverandre. Alle hadde gjort sitt beste, ytt gjennom måneder, vært der heilt til slutt og gjennom det heile. Unge mennesker hadde mestra å bli omsorgspersoner for mor si. Søsken hadde klart å møtes uten filter, i total åpenhet. Nå fikk det utløp, både den store, store sorgen over et altfor tidlig avslutta liv og lettelsen over at det blei en rolig død. I heimen, slik alle ønska. Ei lita uke etter sykesenga var henta, var stuene fylt av blomster. Lys i alle staker. Akkurat slik hun vi mintes ville ha det. Slik var det da hun levde. Slik skulle hun også minnes.

Styrken fra de unge slektningene mine fulgte meg ut døra, ut på veien. Radioen meldte nyheter. Toppsak var helseministerens framlegg av folkehelsemeldingen God helse - felles ansvar. Debatten gikk på hvor mange helsesøstre kommunene vil få for 180 millioner. Og hvor få det er i forhold til behovene. Særlig om det skal tas på alvor at grunnlaget for god helse og inntreden i et langt og friskt arbeidsliv legges i barneog ungdomsårene. At det også dreier seg om å motvirke helsereduserende sosiale og økonomiske forskjeller og øke inkluderingen. Nyhetene blei avslutta med melding om at oljefondet hadde vokst til over 4000 milliarder. Fire tusen milliarder. Jeg prøvde omsette veksten siste kvartal på 320 milliarder i helses $\emptyset$ stre.

Tankene mine flytta seg framover, mot Trondheim, byen hvor jeg arbeider som gateprest og ansvarlig for Vår Frue - åpen kirke. Byens vakreste rom står åpent hver dag, i helgene også om natta for den som måtte trenge ly, ei stille stund, en kaffekopp, et lyttende øre, en hvil fra byens støy. Jeg så for meg noen av ansiktene til mennesker jeg virkelig beundrer. De som møter dag etter dag med åpne sjelelige eller fysiske sår. For det var ikke mange der da grunnlaget for deres helse blei lagt. Ikke helsesøstre som skulle sett omsorgssvikten, skoleinstitusjoner som skulle berget - alt glapp. Nå lever de forvist fra flokken. Samfunnet vårt. Nå går det i selvmedisinering, ofte med stor risiko for ikke å våkne opp. Men blikket er fast om handa er skjelven. Og takknemligheta stor over at ambulansen kom i tide en gang til. Likså stor som sorgen over alt det tapte. Tapt barndom, tapte relasjoner, tapt framtid omtrent fra starten.

Og jeg tenker: Måtte regjeringa virkelig lykkes i å nå sine mål! Måtte «befolkningen oppleve flere leveår med god helse, trivsel og reduserte sosiale helseforskjeller». Måtte vi «skape et samfunn som fremmer helse i hele befolkningen».

Det er et godt utgangspunkt at de sosiale helseforskjellene er erkjent, også konsekvensene av dem - svekka helse og tidligere $d \varnothing d$. Det er et godt utgangspunkt at det er erkjent at vi ennå ikke har et samfunn som fremmer helse i heile befolkninga, at det må skapes. Men hvordan får vi virkelig tatt fatt på arbeidet med å redusere ulikhetene som fører til helseforskjellene og svekka livskvalitet? Til isolasjon og stigmatisering?

Er det noe arbeidet mitt har lært meg, så er det at det er ikke stor forskjell på oss. Vi drømmer om og håper i stor grad på det samme: kjærlighet, fellesskap, en jobb å trives i, tilstrekkelig med penger til ikke å bekymre oss veldig - og at det skal gå godt med ungene. Men det blir gjort forskjell på oss. Og det er det regjeringa erkjenner.

Død er i utgangspunktet det motsatte av god helse. Men måten døden håndteres på og møtes på, styrker oss eller svekker oss. Død er tap. Sorgen er uttrykk for tapet. Der er vi også like. Men grunnlaget for hvordan vi skal klare tapene, er vi mange om å legge. $0 m$ det er sånn at vi tilhører den samme flokken.

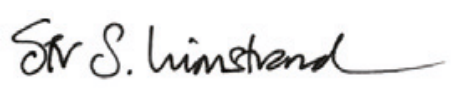

